\title{
The Effect of the Substitution of Ground Corn with Fermented Banana Weevil in the Concentrate Added to the Basal Feed on Blood Metabolite Level of Fattened Bali Cattle by Breeder Pattern
}

\author{
Upik Syamsiar Rosnah; Marthen Yunus; Grace Maranatha; Edi Djoko Sulistijo \\ Faculty of Animal Science, University of Nusa Cendana, Indonesia
}

http://dx.doi.org/10.18415/ijmmu.v6i5.1082

\begin{abstract}
This research is aimed at knowing the effect of the substitution of ground corn with fermented banana weevil in the concentrate as energy sources added to the basal feed of Fattened Bali cattle on the blood metabolite content (blood urea, blood sugar, and total blood proteins). This research was conducted in a field laboratory of Faculty of Animal Science in Oelatsala, Kabupaten Kupang. This research has twelve Fattened Bali cattle at range $2-2.5$ years of age with average body weight $102,71 \mathrm{~kg} \pm 17,58$ $(\mathrm{KV}=17,11 \%)$. The reseach method utilized is a trial method using randomize group design with four treatements and three replications. The treatements in this research are P0: basal feed of breeder pattern + concentrate (contained of $30 \%$ ground corn without fermented banana weevil), P1: basal feed of breeder pattern + concentrate (contained of $20 \%$ ground corn $+10 \%$ fermented banana weevil), P2: basal feed of breeder pattern + concentrate (contained of $10 \%$ ground corn $+20 \&$ fermented banana weevil), P3: basal feed of breeder pattern + concentrate (contained of $30 \%$ fermented banana weevil without ground corn). The data was analyzed using Analysis of Variance (ANOVA). The variable observed includes blood sugar, urea, total blood proteins, and blood cholesterol in Fattened Bali cattle. The result of statistical analysis shows that the substitute ground corn with fermented banana weevil in the concentrate added to the basal feed is not statistically significant $(\mathrm{P}>0.05)$ for the sugar blood, urea, total blood proteins, and blood cholesterol in Fattened Bali cattle. The conclusion of this research is that the substitute ground corn with fermented banana weevil in the concentrate added to the basal feed does not cause different profile of blood metabolite, especially, in terms of blood sugar, urea, total blood proteins, and cholesterol of Fattened Bali cattle.
\end{abstract}

Keywords: Substitute; Fermented Banana Weevil; Concentrate; Blood Metabolite; Fattened Bali Cattle by Breeder Pattern 


\section{Introduction}

The productivity of beef cattle in Nusa Tenggara Timur (NTT) is categorized low in which the average daily weight gain of fattened Bali cattle is only $0,28 \mathrm{~kg} / \mathrm{e} / \mathrm{h}$ (Rosnah and Yunus, 2017), several researchers conclude that the low productivity is caused by the low quality and quantity of feeds. Meanwhile, in fulfilling the cattle's food needs, the breeders get forage in a variation way such as planting and grazing in a potential field. The fattening feed in the level of breeder is Lamtoro (Leucaena leucocephala) in a botanical composition of feed 85,2\% \pm 13.13 (Rosnah dan Yunus 2018). It is on of those cause the balance of nutrients for fattened cattle, especially, between protein and energy is not optimum which is 1:4,2 (Sobang 2005). However, the optimum growth needs PE ratio 1:5,1 (Hogan 1996).

One of the commodities that is agricultural waste and quite potential among breeders is a banana weevil. The nutrient value in the form of high starch that could contribute energy to livestock is expected to substitute ground corn that is mostly used for fulfilling people and other livestock's needs. However, the nutrient content in the form of tannins which causes low digestibility as a feed value makes feeding banana weecil directly to livestock is not recommended. Processing through the fermentation process is needed to decrease anti-nutrition substances, as well as, increase the value of other nutrients such as protein, fat, and extra ingredient without nitrogen. Furthermore, the feeding will be more effective to integrate banana weevil with other feed ingredients in the form of concentrate so that it could be able to rumen microbial activity in digesting basal rations in the breeder pattern. According to Aswadi et al (2012), complete feeding containing banana weevil flour can increase propionic acid production because the banana weevil contains of carbohydrates that are easily digested so that they are suitable for use as feed for the purpose of producing meat (fattening). In order to know the optimaztion of nutritional metabolism of fattened Bali cattle, the chemical profile of blood metabolite contains of blood sugar, urea, total blood proteins, and cholesterol could be observed. Therefore, this research is aimed at knowing the subtition of ground corn with fermented banana weelvil in the concentrate added to the basal feed of fattened Bali cattle by breeder pattern on blood metabolite level.

\section{Materials and Methods}

This research had been conducted from June until September 2018 using 12 male Bali cattle at range 2-2.5 years of age with average body weight $102,71 \mathrm{~kg} \pm 17,58(\mathrm{KV}=17,11 \%)$. The fattened Bali cattle of breeders were gathered in one location and put in individual cages that are equipped with food and drink. The feed used was basal feed and concentrate. Breeders, then, prepard and provided basal feed based on their ability and habitual. The dominant forage basal feed given along the research was lamtoro (Leucaena leucocephala), turi (Sesbania grandiflora), kapuk (Ceiba petandra), busi (Melochiaum bellata), banana stem (Musa acuminata), and concentrate feed consisiting of ground corn, fermented banana weevil, rice bran, gamal flour, salt, and homogenized urea. The banana weelvil is from Kapuk banana (Musa acuminata). The concentrate is given based on treatment that is as much as $1 \%$ of body weight. The fermentor used to ferment the banana weevil is $\mathrm{EM}_{4}$ (Effective microorganism 4) as Guntoro's (2008) guide. 
Table 1. Composition and Nutritional Content of Research Ration

\begin{tabular}{|lcccc|}
\hline \multirow{2}{*}{ Feed ingridients } & \multicolumn{4}{c|}{ Feed Treatement } \\
\cline { 2 - 5 } & $\mathrm{P}_{0}$ & $\mathrm{P}_{1}$ & $\mathrm{P}_{2}$ & $\mathrm{P}_{3}$ \\
\hline Concentrated Feed & & & & \\
Composition: & 50 & 50 & 50 & 50 \\
Rice brain (\%) & 30 & 20 & 10 & 0 \\
Ground Corn (\%) & 0 & 10 & 20 & 30 \\
Farmented Banana Weelvil & & & & \\
Flour (\%) & 15 & 15 & 15 & 15 \\
Gamal Flour (\%) & 3 & 3 & 3 & 3 \\
Urea (\%) & 2 & 2 & 2 & 2 \\
Salt (\%) & & & & \\
Nutritional Content: & 89.17 & 89.01 & 88.75 & 89.34 \\
Dry inggridients (\%) & 88.69 & 88.93 & 87.30 & 86.08 \\
Organic inggridients (\%) & 14.33 & 14.84 & 14.89 & 15.44 \\
Crude protein (\%) & 3.68 & 4.82 & 4.93 & 4.04 \\
Crude fat (\%) & 14.68 & 15.60 & 16.60 & 18.20 \\
Rough fiber (\%) & 55.97 & 53.68 & 50.89 & 48.39 \\
BETN (\%) & 4.06 & 4.13 & 4.07 & 3.99 \\
Energy (Kkal/g) & & & \\
\hline
\end{tabular}

Blood sampling for analytical purposes was conducted in one day in the end of the research or in the end of eight weeks of observation. The sampling taken in vena jugularis utilized venoject that contains of anti quagulant EDTA, then, is put in to the cool box to be analyzed in production biology laboratory in Faculty of Animal Science Nusa Cendana University, East Nusa Tenggara. The reseach method utilized is a trial method using randomize group design with four treatements and three replications. The treatements in this research are $\mathrm{P}_{0}$ : basal feed of breeder pattern + concentrate (contained of $30 \%$ ground corn without fermented banana weevil), $\mathrm{P}_{1}$ : basal feed of breeder pattern + concentrate (contained of $20 \%$ ground corn $+10 \%$ fermented banana weevil), $\mathrm{P}_{2}$ : basal feed of breeder pattern + concentrate (contained of $10 \%$ ground corn $+20 \&$ fermented banana weevil), $\mathrm{P}_{3}$ : basal feed of breeder pattern + concentrate (contained of $30 \%$ fermented banana weevil without ground corn). The data was analyzed using Analysis of Variance (ANOVA) (Stell and Torie 1993).

The variable observed in this research are profile of blood metabolite includes blood sugar, urea, total blood proteins, and cholesterol of Fattened Bali cattle. The level of sugar blood is observed by GODPAP method (Dias, 1999). The calculation of glucole is (Abs sample/Abs standard) x $100 \mathrm{mg} / \mathrm{dl}$. The level of urea was observed using the method of enzymatic calorimetria of Beckman Shynchorn LX20 (Henry, 1991). The calculation of urea is (Abs. sample/Abs. standard) $x 50 \mathrm{mg} / \mathrm{dl}$. The level of total proteins $(\mathrm{g} / \mathrm{dl})$ was observed using Biuret method. The level of cholesterol $(\mathrm{mg} / \mathrm{dl})$ was observed using cholesterol oxidase (CHOD-PAP) method (Hans et al 1980). The calculation of cholesterol level is (Abs. sample/Abs. standard) x200mg/dl. 


\section{Results and Discussion}

Picture of blood metabolites, especially, in glucose, urea, protein, and cholesterol represents the physiological picture of livestock that shows the results of nutritional metabolism and the wuality of the ration consumed. Below the effect of treatement over level of glucose, urea, total plasma protein, and cholesterol.

Tabel 2. Average level of glucose, urea, total plasma protein, and cholesterol of fattened Bali cattle by breeder pattern that are given concentrated corn source energy substitute and fermented banana weelvil

\begin{tabular}{|c|c|c|c|c|c|c|}
\hline \multirow{2}{*}{ Parameter } & \multicolumn{4}{|c|}{ Treatement } & \multirow[b]{2}{*}{ Average } & \multirow[b]{2}{*}{ P-Value } \\
\hline & $\mathrm{P}_{0}$ & $\mathrm{P}_{1}$ & $\mathrm{P}_{2}$ & $\mathrm{P}_{3}$ & & \\
\hline Glucose (mg/dl) & 74.81 & 71.37 & 74.20 & 76.50 & 74.28 & $0,84^{\mathrm{ns}}$ \\
\hline Urea $(\mathrm{mg} / \mathrm{dl})$ & 44.36 & 43.22 & 40.59 & 40.77 & 42.23 & $0,25^{\mathrm{ns}}$ \\
\hline Total Plasma Protein (g/dl) & 7.33 & 7.53 & 7.13 & 7.60 & 7.4 & $0,76^{\mathrm{ns}}$ \\
\hline Cholesterol (mg/dl) & 212.28 & 217.67 & 191.93 & 214.83 & 209.18 & $0,21^{\mathrm{ns}}$ \\
\hline
\end{tabular}

The result of analysis of variance shows that addition of concentrated energy sources for the substitution of corn and fermented banana weelvil in basal feed of fattened Bali cattle provides metabolite profile, especially, in terms of glucose, urea, total plasma protein, and cholesterol which is not significant $(\mathrm{P}>0.05)$. The ration given for livestock in this research has similar quality that has not significant effect. This is caused by the consumtion of organic ingredient in each treatemets is $3,08 \mathrm{~kg} / \mathrm{e} / \mathrm{h}(\mathrm{P} 1) ; 3,26 \mathrm{~kg} / \mathrm{e} / \mathrm{h}$ $(\mathrm{P} 2) ; 3,28 \mathrm{~kg} / \mathrm{e} / \mathrm{h}(\mathrm{P} 3), 3,39 \mathrm{~kg} / \mathrm{e} / \mathrm{h}(\mathrm{P} 4)$ while the average digestibility of organic matter for each treatement is $58,60 \%(\mathrm{P} 1) ; 58,48 \%(\mathrm{P} 2) ; 61.96 \%(\mathrm{P} 3)$ dan $58,32 \%(\mathrm{P} 4)$. This condition reflects the almost equal supply for nutrients so that the level of blood metabolite of fattened Bali cattle has no significant different.

Blood glucose in ruminants as an important source of energy is needed in large quantities for basic living needs, body growth, fetus growth, body tissue growth, and production (Parakkasi, 1991). The level of blood glucose as a reflection of energy supply for livestock in all four treatements has no significant value $(\mathrm{P}>0.05)$, the level of glucose in each treatments is $\mathrm{P} 0(74.81 \mathrm{mg} / \mathrm{dl}), \mathrm{P} 1(71.37 \mathrm{mg} / \mathrm{dl})$, $\mathrm{P} 2(74.20 \mathrm{mg} / \mathrm{dl}), \mathrm{P} 3(76.50 \mathrm{mg} / \mathrm{dl})$ and average is $74.28 \mathrm{mg} / \mathrm{dl}$ which is in normal range $43-100 \mathrm{mg} / \mathrm{dl}$ (Mitruka et al 1977). The non significant value of glucose in each treatemets is caused by the consumption of organic material that is metabolized by livestock responds to the content of organic material in rations that are almost the same (Table 1) and the no significant consumption level and digestibility of organic matter. The complete feeding contains banana weelvil flour could increase propionate acid production in rumen of goat livestock because banana weevil contains of carbohydrates that are easily digested so that they are suitable for use as feed for the purpose of producing meat (fattening) (Aswadi dkk 2012). The source of glucose in ruminants is propionate acid, lactic acid, protein, and glycerol. Propionate is the result of carcohydrate fermented in rumen. The propionate could be increase by giving more concentrate with carbohydrate that is easily digested. Thus, the value of glucose has a correlation with energy consumption. If the energy consumption is high, the glucose level will be also high (Parakasi, 1999). In this treatement, the constituents of energy sources in different concentrates are ground corn and fermented banana weelvil produce the level of glucose that is relatively the same. This result is higher that Wuda's (2017) report in the research of addition of concentrate containing 
banana peel four that shows average of glucose level is $67.11 \mathrm{mg} / \mathrm{dl}$. This might be the result of the high level of feed digestibility.

The blood urea levels can be used as an index of protein, as a function of absorbing ammonia from rumen, and efficient use of protein at the tissue level. The urea level of fattened Bali cattle were given four treatements which are P0 (44.36mg/dl), P1 (43.22mg/dl), P2 (40.59mh/dl), P3 (40.77mg/dl) with average $42.23 \mathrm{mg} / \mathrm{dl}$, which shows, statistically, has no significant effecr $(\mathrm{P}>0.05)$. The blood urea level in this research has a hig potential since there is a positive relationship between blood urea and protein of the feed consumed by the livestock in which is dominated by lamtoro (Leucaena leucocephala) as a source of protein in botanical composition of feed which is 85.2\% \pm 13.13 (Rosnah dan Yunus 2018). However, it still belongs to the normal range for ruminant livestock that is $26.5-56.6 \mathrm{mg} / \mathrm{dl}$ (Hungate 1966). The no significant difference of level of urea might be a result of $\mathrm{N}$-amoniac production in the rumen of all four treatements that the results of concentration feed that contains of ground corn and fermented banana weelvil. The efficient utilization of $\mathrm{NH} 3$ for protein synthesis in the rumen depends on energy availability. If there is lack of energy, the protein will be too much so that it cannot be used by rumen microba.

The total plasma protein is a complex mix that contains of simple protein and mix protein like glycoprotein and lipoprotein. The total plasma protein functions as source of protein replacement in tissue that lacks protein. The level of total plasma protein of fattened Bali cattle giving four treatements is $\mathrm{P} 0$ $(7.33 \mathrm{~g} / \mathrm{dl}), \mathrm{P} 1(7.53 \mathrm{~g} / \mathrm{dl}), \mathrm{P} 2(7.13 \mathrm{~g} / \mathrm{dl}), \mathrm{P} 3(7.60 \mathrm{~g} / \mathrm{dl})$ with average $7.4 \mathrm{~g} / \mathrm{dl}$, statistically shows no significant effect $(\mathrm{P}>0,05)$. The non significant value of protein in each treatemets is caused by the consumption of organic material that is metabolized by livestock responds to the content of organic material in rations that are almost the same (Table 1) and the no significant consumption level and digestibility of organic matter. The total plasma protein in this research is high, possibly due to a positive relationship with the type of basal feed which is dominated by lamtoro as a source of protein. Plasma protein is a combination of dietary protein that escapes from rumen degradation and microbial protein carried along with the outgoing feed from the post rumen digestive tract. Microbial protein is related to the growth of rumen microbes and VFA production as the main ingredient for rumen microbial protein formation. The total plasma protein, however, is in the normal range for ruminant livestock at $6.0-$ $8.0 \mathrm{~g} / \mathrm{dl}$ (Wahyuni dan Binjati 2006). The result is lower than WUda's (2017) report which is report in the research of addition of concentrate containing banana peel four that shows average $8.61-9.72 \mathrm{~g} / \mathrm{dl}$, while it is relatively the same when compared to report of Samba (2016) which is addition of concentrate containing unfermented banana peel four that is $7.20-7.60 \mathrm{~g} / \mathrm{dl}$. The level of cholesterol in four treatements has no significant difference which is P0 (212.28mg/dl), P1 (217.67mg/dl), P2 (191.93mg/dl), P3 (214.83mg/dl) with average $209.18 \mathrm{mg} / \mathrm{dl}$ (Table 2). It might be caused by the provision of quality ration that is almost the same in which, certainly, supply the almost same nutrition. The blood cholesterol level are influenced by consumption of dry matter and crude fat feed that provides cholesterol precursor which is Asetil-KoA and glucose as well as catabolism of fatty acids and amino acids in the mitochondria. According to Turk et al (2004), normal range of blood cholesterol in cattle is 130-252 mg/dl.

\section{Conclusions}

The result of this research is the substitution of ground corn with banana weelvil in the concentrate on the basal fed of the breeder pattern does not cause a difference in the profile of blood metabolites, especially, in glucose, urea, total plasma protein, and blood cholesterol of fattened Bali cattle.

\section{Acknowledgement}


1. Directorate of Research and Community Service, Minister of Research and Technology of Directorat General of Higher Education which has funded this reseacrh.

2. Research team: Ir. Marthen Yunus dan Ir Grace Maranatha, MSi., a breeder in Oelatsala village, juniors of Faculty of Animal Science involved in the research model of increasing performance in fattened Bali cattle production at the farmer level through feed suplementation containing fermented banana weevil flour.

3. The chairman of LP2M Nusa Cendana University and his staff

4. Deen of the Faculty of Animal Science Nusa Cendana University Kupang

\section{References}

Upik Syamsiar Rosnah dan Marten Yunus. 2017. Productivity Of Fattened Bali Cattle Consuming Local Feeds At A Local Rearing Sytem. Prosiding Seminar Nasional Peternakan III "Hilirisasi Teknologi Dalam Sistem Peternakan Lahan Kering Mendukung Swasembada Daging Nasional. ISBN: 978602-6906-34-2. Halaman 170-173.

Upik Syamsiar Rosnah dan Marten Yunus. 2018. Feeds compositions and feeding amount of bali cattle fattened on traditional system. Jurnal Nukleus Peternakan (Juni 2018), Volume 5, No. 1:24-30.

Sobang, Y.U.L. 2005. Karakteristik sistim penggemukan sapi pola gaduhan menurut zona agroklimat dan dampaknya terhadap pendapatan petani di Kabupaten Kupang Nusa Tenggara Timur.Buletin Nutrisi, Volume 8, No. 8. ISSN: 1410-6191. Halaman 71-76.

Hogan, J.,1996. Principles of Suplementary Feeding Dalam Ruminant Nutrition and Production in The Tropics and Subtropics. Editor: B.Bakrie, J. Hogan, J.B.Liang, A.M.M.Tereque, and R.C.Upadhyay. Australian Center for International Agricultural Research. Canbera.

Aswadi, C.I. Sutrisno., M. Arifin dan Joelal. 2012. Efek complete feed bonggol berbagai varietas tanaman pisang terhadap ph, nh3 dan vfa pada kambing kacang. Jurnal Ilmu Teknologi Peternakan. Vol. 2.

Guntoro, S., Sriyanto, N. Suyasa dan M.R.Yasa, 2008. Pengaruh Pemberian Limbah Kakao Olahan Terhadap Pertumbuhan Sapi Bali. Balai Pengkajian Teknologi Pertanian Bali, Ngurah Rai, Denpasar.

Steel, R., Torrie, HJ. 1993. Prinsip Dan Prosedur Statistik.. Gramedia Pustaka. Jakarta.

Dias, T S. 1991. Leaflet Glucose GOD PAP. Diacnostic System. (Dasys).

Henry, J,B. 1991. Clinical Diagnosis and manajement by laboratory method; $18^{\text {th }}$ Ed. Philadelphia: W.B. Sounders.

Hans F, Prafulla A, Heide K, Ingeborg K, 1980. Use of simple enzymatic assay for cholesterol analiysis in human bile. Journal of lipid research21 (1): 259.

Parakkasi, A. 1999. Ilmu Nutrisi dan Makanan Ternak Ruminan. Penerbit Universitas Indonesia. Jakarta. 
Mitruka B M, Rawnsley H M and Vadehra B V. 1977. Chilical biochemical and ematological refence values in normal experiment animals. Masson Publishing, inc., New York.

Wuda I, 2017.Pengaruh pemberian konsentrat yang mengandung tepung kulit buah pisang terhadap hematologis sapi Bali penggemukan pola peternakan rakyat. Skripsi. Fakultas Peternakan Universitas Nusa Cendana. Kupang.

Hugate, R,E. 1966. The rumen and its microbes. Academic Press. New York.

Samba, F. D. 2016. Effect of feeding concentrate containing banana wen meal on dry mater, organic mater intakes and total protein plasma of fattening Bali cattle kept as local farmer pattern. Skripsi Fakultas Peternakan Undana.

Turk R, D JUretic, D Geres, N Turk, B Rekie, Simeon R and A Svetina. 2004. Serum paraoxonase activity and lipid parameters in the early post partum period of dairy cows. Reseach in veterinary science. 76: 57-61

\section{Copyrights}

Copyright for this article is retained by the author(s), with first publication rights granted to the journal.

This is an open-access article distributed under the terms and conditions of the Creative Commons Attribution license (http://creativecommons.org/licenses/by/4.0/). 